\title{
PENGEMBANGAN ASESMEN HASIL BELAJAR PENJASORKES SISWA SMA PADA PERMAINAN BOLAVOLI
}

\author{
${ }^{1)}$ Guntur, ${ }^{2)}$ Sukadiyanto, ${ }^{3)}$ Djemari Mardapi \\ ${ }^{1,2)}$ Fakultas Ilmu Keolahragaan Universitas Negeri Yogyakarta, \\ ${ }^{3)}$ Fakultas Teknik Universitas Negeri Yogyakarta \\ ${ }^{1)}$ guntursetiyonos@yahoo.co.id, ${ }^{2)}$ sukadiyanto_fik@yahoo.com, ${ }^{3)}$ djemarimardapi@gmail.com
}

\begin{abstract}
Abstrak
Penelitian ini bertujuan menghasilkan instrumen asesmen yang valid dan reliabel untuk mengukur hasil belajar pendidikan jasmani olahraga dan kesehatan siswa SMA pada permainan bolavoli. Penelitian pengembangan mengadopsi penelitian pengembangan Borg and Gall dengan 10 langkah. Uji coba skala kecil dilakukan pada siswa Sekolah Laboratorium Olahraga FIK UNY yang berjumlah 24 anak dan uji coba skala besar pada siswa SMAN 1 Yogyakarta, SMAN 2 Wates, SMAN 1 Seyegan, SMAN 1 Sewon, dan SMAN 1 Tanjung Sari berjumlah 120 anak. Instrumen pengumpul data berupa pedoman observasi, sedangkan analisis data dengan menggunakan analisis diskriptif. Hasil penelitian ini adalah instrumen pengamatan hasil belajar siswa penjasorkes pada permainan bolavoli yang memiliki indikator, deskripsi, rubrik, prosedur asesmen. Validitas isi berdasarkan expert judgement termasuk kategori baik dan reliabilitas interrater dengan paket program Genova menghasilkan koefisen sebesar 0,82, dan Cohen's Kappa sebesar 0,79. Kesimpulan penelitian berdasarkan pendapat para guru ialah instrumen ini dapat digunakan untuk mengukur hasil belajar penjasorkes siswa SMA pada permainan bolavoli.
\end{abstract}

Kata kunci: asesmen hasil belajar, pendidikan jasmani olahraga dan kesehatan, permainan bolavoli

\section{DEVELOPING THE ASSESSMENT OF LEARNING OUTCOMES FOR THE STUDENT OF PHYSICAL, SPORTS, AND HEALTH EDUCATION IN VOLLEYBALL GAME FOR SENIOR HIGH SCHOOLS}

\author{
${ }^{1)}$ Guntur, ${ }^{2)}$ Sukadiyanto, ${ }^{3)}$ Djemari Mardapi \\ ${ }^{1,2)}$ FIK Universitas Negeri Yogyakarta, ${ }^{3)}$ FT Universitas Negeri Yogyakarta \\ ${ }^{1)}$ guntursetiyonos@yahoo.co.id, ${ }^{2)}$ sukadiyanto_fik@yahoo.com, ${ }^{3)}$ djemarimardapi@gmail.com
}

\begin{abstract}
This study aims to produce valid and reliable assessment instruments and to measure the learning outcomes for the students of physical, sport and health education in volleyball game for senior high schools. The research and development model chosen was the model developed by Borg \& Gall, with a procedure consisting of ten stages. The field test sample consisted of the 24 students of the sports laboratory school for volleyball of the Faculty of Sports Science, Yogyakarta State University and the large-scale tests were on students of SMAN 1 Yogyakarta, Wates SMAN 2, SMAN 1 Seyegan, SMAN 1 Sewon, and SMAN 1 Tanjung Sari totaling 120 students. The instrument to collect data was observation sheet, whereas data analysis used descriptive analysis. The result of the study is an instrument for assessing the learning outcomes of physical, sports, and health education for the volleyball game that includes indicators, descriptions, and rubrics of performances, and the content validity game based on expert judgment which is good based on expert judgment; Reliability coefficient of the instrument for assessing the practice of the volleyball game by means of the Genova package program is 0.82 and that by means of Cohen's Kappa is 0.79 , both satisfy the reliability requirements. Based on the the teachers' opinions, these instruments can be used to measure student learning outcomes of physical, sport and health education at volleyball game in high schools.
\end{abstract}

Keywords: assessment of learning outcomes, physical sports and health education, volleyball game 


\section{Pendahuluan}

Peranan penting pendidikan jasmani di sekolah adalah memberikan kesempatan kepada siswa untuk terlibat langsung dalam berbagai pengalaman belajar melalui aktivitas jasmani yang dipilih dan dilaksanakan dengan sistematis (Lutan, 2001, p.17). Pendidikan jasmani olahraga dan kesehatan (penjasorkes) merupakan bagian integral dari pendidikan di SMA. Dalam kurikulum kelompok mata pelajaran ini, siswa dituntut untuk dapat menguasai suatu standar kompetensi.

Materi permainan merupakan salah satu standar kompetensi yang harus dikuasai siswa dalam pembelajaran penjasorkes di sekolah menengah atas. Permainan merupakan salah satu cabang olahraga yang diharapkan mampu mengembangkan siswa sesuai dengan tujuan pendidikan yang ingin dicapai. Pada umumnya manusia, baik anakanak maupun orang dewasa senang bermain, dari rasa senang bermain inilah mudah diketahui keadaan sebenarnya tiap orang yang bermain, sebab secara spontan berbicara, bertindak dan bertingkah laku sesuai dengan kebiasannya. Dengan demikian, permainan dapat digunakan sebagai alat untuk memacu potensi siswa yang berupa gerak, sikap dan perilaku dalam pembelajaran.

Berdasarkan karakteristik permainan ini, dalam mata pelajaran penjasorkes, khususnya permainan bolavoli digunakan oleh guru sebagai media untuk mencapai tujuan pembelajaran berbasis kompetensi. Pembelajaran tersebut menekankan pada pengembangan kemampuan siswa dalam melakukan tugas-tugas dengan unjuk kerja sehingga hasil pembelajarannya berupa penguasaan seperangkat kompetensi.

Dalam rangka proses pengumpulan bukti tentang pencapaian hasil belajar siswa penjasorkes pada permainan bolavoli melibatkan suatu ujian, pengukuran dan asesmen yang dilakukan pada tengah dan ahkir pembelajaran. Pelaksanaan asesmen hasil belajar siswa pada mata pelajaran pendidikan jasmani akan berjalan dengan baik apabila ditunjang oleh para guru yang telah memiliki pengetahuan dan pemahaman tentang tes, dan cara menyusunnya sesuai karakteristik materi (Nurhasan, 2001, p.9). Kemampuan melaksanakan suatu asesmen hasil belajar pada siswa merupakan salah satu keterampilan profesional yang harus dikuasai oleh guru. Keberhasilan dalam melaksanakan asesmen hasil belajar ini akan sangat ditentukan oleh kemampuan guru dalam mengkonstruksi alat ukur, dan menggunakan alat ukur yang telah dikonstruksi itu dengan cara yang benar, serta kemampuan menganalisis data informasi yang dihasilkan oleh alat ukur itu. Apabila keseluruhan kemampuan itu tidak dikuasai oleh guru, maka kemungkinan besar akan terjadi kesalahan dalam pengukuran hasil belajar, yang pada gilirannya akan mengakibatkan kerugian bagi siswa.

Asesmen hasil belajar siswa yang sudah dilaksanakan oleh para guru penjasorkes materi permainan bolavoli selama ini menggunakan tes keterampilan cabang olahraga (sport skills tests). Tes keterampilan tersebut suatu tes simulasi yang diadopsi menyerupai situasi olahraganya bertujuan untuk mengukur keterampilan para siswa dalam suatu cabang olahraga.

Jenis tes keterampilan olahraga bermain bolavoli yang sudah ada, di antaranya; AAPHER serving accuracy test, Brumbach forearm pass wall-volley test, Kautz, volleyball passing test, AAPHER face pass wall-volley test, Stanley spike test dan Brady wall-volley test. Selama digunakan oleh para guru penjas sebagai alat ukur keterampilan siswa bermain bolavoli, keenam tes tersebut masih memiliki kelemahan-kelemahan di samping kelebihan yang ada.

Tes AAPHER serving accuracy test lebih mengarah pada pengukuran kemampuan servis, yaitu dilakukan dengan teste berada dalam daerah servis dan melakukan servis bola pada lapangan. Tes Brumbach forearm pass wall-volley test untuk mengukur kemampuan passing bawah, yaitu teste melakukan passing bawah dengan sasaran pada tembok. Tes AAPHER face pass wall-volley test untuk mengukur kemampuan passing atas atau umpan, yaitu teste melakukan passing atas dengan sasaran pada tembok. Tes Brady 
wall-volley test untuk mengukur keterampilan bermain bolavoli, yaitu teste melakukan passing bawah dan passing atas dengan sasaran pada tembok. Tes Stanley spike test untuk mengukur kemampuan spike atau smash, yaitu teste berada di dalam daerah bebas dan melakukan smash dalam lapangan.

Kelemahan dari AAPHER serving accuracy test dan Stanley spike test adalah harus tersedia lapangan yang berukuran $9 \times 18 \mathrm{~m}$. Sedangkan pada Brumbach forearm pass wallvolley test, Kautz volleyball passing test, AAPHER face pass wall-volley test dan Brady volley test harus tersedia tembok sasaran berukuran 5 × 6 feet dengan tinggi 10 feet dari lantai. Selain itu, tes keterampilan olahraga bolavoli berbentuk simulasi tersebut memerlukan peralatan dan tempat yang lebih banyak karena antara butir tes yang satu dengan butir tes lainnya dilakukan secara terpisah sehingga kurang efektif dan efisien bila digunakan untuk mengukur siswa dalam jumlah banyak.

Kelemahan penggunaan tes keterampilan olahraga ini merupakan prediktor yang dianggap tidak valid dalam mengukur kemampuan siswa saat bermain sesungguhnya karena keterampilan siswa dari hari ke hari tidak tetap dan keterampilan yang biasanya diujikan pada siswa keluar dari konteks (Veal, 2002, p.88). Jenis tes tersebut banyak mengukur pada aspek hasil yaitu pada ketepatan bola dan belum mengukur pada aspek proses berupa tahapan-tahapan gerak yang baik dan benar pada suatu teknik atau cara memainkan bola, di samping itu tes ini sebenarnya cocok untuk mengukur kemampuan atlet profesional dan tidak relevan untuk mengukur kompetensi siswa di sekolah.

Model asesmen yang diharapkan dalam pendidikan jasmani mampu mengukur kompetensi siswa dalam konteks kehidupan nyata adalah penilaian unjuk kerja (Mitchell, 1999, p.19). Asesmen unjuk kerja dalam mata pelajaran pendidikan jasmani memungkinkan guru untuk melihat kompetensi siswa yang teramati dalam bermain permainan bolavoli secara nyata.

Asesmen unjuk kerja (performance assessment) permainan bolavoli adalah asesmen yang meminta peserta tes untuk melakukan unjuk kerja bermain bolavoli pada situasi nyata sesuai kriteria yang diharapkan dan dapat diaplikasikan secara aktual. Pada asesmen ini ditinjau beberapa aspek dalam asesmen yaitu proses dan hasil yang dilakukan siswa dalam bermain bolavoli. Kedua aspek asesmen ini akan memberikan gambaran tentang kompetensi siswa yang sebenarnya.

Dalam asesmen proses seorang guru dapat mengamati bagaimana ketepatan pelaksanaan gerak siswa dalam tahapan persiapan saat akan memainkan bola berupa keterampilan siswa menyiapkan sikap awal tubuh, gerak awal, gerak perkenaan bola dan gerak lanjut sesuai teknik atau cara yang akan digunakan dalam memainkan bola. Pada asesmen produk seorang guru dapat melihat hasil penempatan bola siswa setelah mengalami serangkaian proses teknik atau cara memainkan bola dalam bermain bolavoli dan nilai-nilai berupa sikap kerja sama dan sportivitas siswa dalam bermain.

Permasalahan yang sering dihadapi guru pendidikan jasmani dalam melakukan asesmen unjuk kerja terletak pada validitas dan reliabilitas alat ukur yang digunakan. Penyusunan tes unjuk kerja siswa masih sangat terbatas pada pengetahuan dan pemahaman guru tentang tes berbentuk simulasi. Hasil asesmen sering dipengaruhi oleh subjektivitas guru sebagai rater karena dalam melakukan asesmen dilakukan sendiri tanpa melibatkan guru yang lain sebagai kolabolator.

Berdasarkan latar belakang di atas, maka perlu dikembangkan suatu instrumen asesmen hasil belajar siswa penjasorkes pada permainan bolavoli yang menghasilkan alat asesmen berguna bagi guru untuk mengumpulkan informasi pencapaian kompetensi siswa. Diharapkan instrumen ini bermanfaat secara optimal untuk meningkatkan kualitas pembelajaran pendidikan jasmani di jenjang SMA.

Mardapi (2012, p.12), berpendapat bahwa penilaian atau asesmen merupakan komponen penting dalam penyelenggaraan pendidikan. Upaya meningkatkan kualitas 
pendidikan dapat ditempuh melalui peningkatan kualitas pembelajaran dan kualitas sistem penilaianya. Keduanya saling terikat, sistem pembelajaran yang baik akan menghasilkan kualitas belajar yang baik. Kualitas pembelajaran ini dapat dapat dilihat dari hasil penilaiannya.

Asesmen adalah proses pengumpulan data secara sistematis untuk membuat keputusan tentang seseorang (Berk, 1986, p.ix). Asesmen mencakup semua cara yang digunakan untuk mengumpulkan data tentang individu sehingga keputusannya juga terhadap individu (Mardapi, 2012, p.13). Data yang diperoleh dengan berbagai cara kemudian diolah menjadi informasi tentang individu. Jadi proses asesmen meliputi pengumpulan bukti tentang pencapian hasil belajar siswa. Berdasarkan pendapat tersebut maka dapat disimpulkan bahwa asesmen adalah semua cara yang digunakan untuk mengumpulkan data tentang individu.

Peranan penting asesmen hasil belajar adalah untuk menentukan capaian belajar siswa (Jennifer, 2009, p.33). Menurut Els van der Werf (2006, p.17) hasil belajar adalah kemampuan yang bisa dihasilkan siswa yang melibatkan pengukuran pada ranah kognitif, afektif dan psikomotor yang secara terpadu dikaitkan dengan seluruh domain perkembangan siswa itu sendiri.

Asesmen hasil belajar siswa pada kelompok mata pelajaran penjasorkes dilakukan melalui pengamatan terhadap perubahan perilaku dan sikap untuk menilai perkembangan psikomotor dan afektif siswa (BSNP, 2007, p.17). Asesmen yang dilakukan guru mencakup semua hasil belajar siswa yaitu kemampuan kognitif atau berpikir, kemampuan psikomotor atau kemampuan praktik, dan kemampuan afektif, namun penekanan pada setiap ranah tidak sama sehingga harus diperhatikan karakteristik mata pelajaran yang akan diukur (Mardapi, 2012, p.15). Penilaian capaian hasil belajar pada tingkat kognitif yang lebih tinggi (bigher-order thinking), menurut Nitko dan Brookhart (2007, p.208) dibutuhkan tes (task) yang menuntut peserta didik untuk menggunakan pengetahuan dan keterampilan dalam situasi yang baru (new or novel situations). Dengan demikian, peserta didik tidak hanya dituntut untuk memahami, tetapi sampai mampu untuk menganalisis, mengevaluasi dan berkreasi.

Penilaian penguasaan kompetensi aspek keterampilan atau psikomotor siswa di mata pelajaran pendidikan jasmani dilakukan dengan penilaian unjuk kerja (performance assessment) (Metzler, 2005, p.178). Dalam rangka untuk mengetahui capaian hasil pembelajaran berbasis kompetensi melibatkan penggunaan suatu sistem asesmen kompetensi. Hayton dan Wagner(1998, p.71) menyatakan performance assessment is a technique that is likely to be used in a competency-based system because both the system and the technique have a focus on criterion activities or outcomes.

Menurut Stiggins, R (1997, p.34) "performance assessments call upon the examinee to demonstrate specific skills and competencies, that is, to apply the skills and knowledge they have mastered". Wiggins, G (1993, p.57) menekankan hal yang lebih unik lagi perlunya kinerja ditampilkan secara efektif dan kreatif. Selain itu, tugas yang diberikan dapat berupa pengulangan tugas atau masalah yang analog dengan masalah yang dihadapi. Hal yang penting dalam penilaian unjuk kerja adalah cara mengamati dan menskor kemampuan kinerja peserta didik.

Guna meminimalkan faktor subjektivitas keadilan dalam menilai kemampuan kinerja peserta didik, biasanya rater atau penilai jumlahnya lebih dari satu orang sehingga diharapkan hasil penilaian mereka menjadi lebih valid dan reliabel. Di samping itu, dalam pelaksanaan penilaian diperlukan suatu pedoman penilaian yang bertujuan untuk memudahkan penilai dalam menilai sehingga tingkat subjektivitas bisa ditekan.

Penilaian pada domain afektif dalam pendidikan jasmani sangat penting dilakukan karena sebagian besar aktivitasnya melibatkan interaksi dengan orang lain dan hanya melalui interaksi sosial kualitas siswa melakukan pembelajaran sepenuhnya mencapai sasaran (Vicki Worrell, 2002, p.9). Penilaian aspek afektif pada mata pelajaran penjas sebaiknya lebih ditekankan kepada internalisasi nilai-nilai sikap siswa berupa 
kerja sama yang ditampilkan dalam proses mempraktikkan suatu permainan (Grineski, S. 1989, p.21). Kegiatan pendidikan jasmani penuh dengan kesempatan untuk mengajarkan keterampilan psikososial seperti kerjasama dan sportivitas (Tomme \& Wendt, 2003, p.68). Menurut Vicki Worrell (2002, p.7) penilaian yang efektif pada domain ini memerlukan sasaran pengukuran dari unsur-unsur afektif salah satu unsurnya yaitu interaksi interpersonal seperti sportivitas sebagai tujuan belajar siswa dalam pendidikan jasmani.

Sportivitas adalah menjadi olahragawan (sportman) yaitu orang yang dapat mengambil kerugian atau kekalahan tanpa keluhan atau kemenangan tanpa sombong dan yang memperlakukan lawan-lawannya dengan keadilan, kemurahan hati, dan sopan (Keating, 2001, p.12). Penilaian pada permainan olahraga bolavoli dilakukan terutama pada aspek kemampuan siswa menampilkan sikap dalam bermain terutama pada kerja sama dan sportivitas ketika melaksanakan bermain yang dilakukan dengan cara, antara lain: observasi perilaku.

Mata pelajaran Pendidikan Jasmani, yang dalam kurikulum disebut secara paralel dengan istilah lain menjadi Pendidikan Jasmani, Olahraga dan Kesehatan, merupakan salah satu mata pelajaran yang disajikan di sekolah, mulai dari SD sampai dengan SMA. Menurut Jewett dan Nixon (1995, p.27), pendidikan jasmani adalah satu aspek dari proses pendidikan keseluruhan yang berkenaan dengan perkembangan dan penggunaan kemampuan gerak individu yang sukarela dan berguna serta berhubungan langsung dengan respon mental, emosional dan sosial.

Menurut Pettifor (1999, p.134), pendidikan jasmani menyediakan siswa untuk mengamalkan hidup aktif dan sehat dengan menyediakan cakupan pengalaman-pengalaman pembelajaran yang rapi dan sistematis. Artinya, pendidikan jasmani membekali ruang untuk membentuk siswa yang mantap secara seluruhnya (whole child) yang diarahkan pada pembangunan aspek-aspek kognitif, afektif dan psikomotor.
Penjasorkes merupakan satu-satunya mata pelajaran di sekolah yang menggunakan gerak sebagai media pembelajaran untuk mencapai tujuan pendidikan. Wuest dan Bucher (2009, p.97) menyebutkan, "Movement is the Keystone of Physical Education and Sport." Jelas dinyatakan bahwa gerak merupakan kunci dari pendidikan jasmani dan olahraga. Menurut Lutan (2001, p.15) proses belajar untuk bergerak dan belajar melalui gerak merupakan dua makna yang patut dipegang dalam penjasorkes.

Pembelajaran pendidikan jasmani diajarkan dengan berbagai keterampilan gerak teknik dan strategi permainan/olahraga, internalisasi nilai sportivitas, dan kerja sama (Asmawi, 2006, p.134). Melalui suatu gerakan siswa dituntun untuk mengetahui cara melakukan gerakan tersebut, mengetahui kebermanfaatan gerakan tersebut dan juga mampu menunjukkan perilaku-perilaku positif selama pembelajaran yang diharapkan mampu juga diwujudkan siswa dalam kehidupannya sehari-hari.

Dalam mata pelajaran pendidikan jasmani olahraga dan kesehatan di sekolah menengah digunakan permainan bolavoli sebagai salah satu materi pembelajaran gerak. American Sport Education Program (2007, p.22) menyatakan permainan bolavoli adalah sebagai berikut: Volleyball is unique in that it is a game of errors where the objective is to get the ball to bit the floor on the opponent's side of the net or force the opponent to make ballhandling error. Thus, the majority of points scored in volleyball are result of an error.

Konsep dan prinsip bolavoli menurut Yudiana \& Subroto (2010, p.36) permainan bolavoli pada awal ide dasarnya adalah permainan memantul-mantulkan bola (to-volley) oleh tangan atau lengan dari dua regu yang bermain di atas lapangan yang mempunyai ukuran-ukuran tertentu. Untuk masingmasing regu, lapangan di bagi dua sama besar oleh net atau tali yang dibentangkan di atas lapangan. Lapangan di bagi dua sama besar oleh net atau tali yang dibentangkan di atas lapangan dengan ukuran ketinggian tertentu. Satu orang pemain tidak boleh memantulkan bola dua kali secara berturut- 
turut kecuali pembendung, dan satu regu dapat memainkan bola maksimal tiga kali sentuhan di lapangan sendiri.

Pembelajaran dasar permainan bolavoli dapat bertujuan untuk kesenangan, lebih lanjut menurut Joel (2003, p.vii), "volleyball is a unique, exciting game that requires solid teamwork and consistent individual execution". Keunikan bolavoli tidak seperti olahraga lain karena dalam bermain selain harus adanya unsur kerja sama tim sehingga tanpa kerja sama tim tidak akan bisa melakukan serangan dengan tepat (Kinda, 2006, p.v). Bolavoli sebagai olahraga tim memiliki karakteristik yang unik yaitu memiliki aturan bermain, menggunakan lapangan berukuran 18x9 m dan dibatasi net. Permainan bolavoli menurut jenis klasifikasi permainannya termasuk pada jenis net games (Hopper, 1998, p.17). This primary rule leads to progressive principles of play that are consistency, then placement of the object and positioning in relation to opponent's target area, and finally spin and power to make it difficult for an opponent to get the object back into play (Hopper, 1998, p.18). Permainan ini berkaitan dengan beberapa hal yaitu melakukan rally secara konsistensi, penempatan bola pada target lawan atau daerah lawan, dan keterampilan untuk memukul bola dengan teknik yang dipilih untuk mematikan lawan.

Menurut Crum (2006) bolavoli adalah rallying versus playing to the ground, to hit (or touch) somebody's field (or the field of the other tim) with an object (for example a ball) with respect to prevent that or to hit (or touch) somebody's field (or the of other team) that way the other person (or team) the object can't return (in my our field). Menurut Viera, (2004, p.4) rally adalah permainan bola menyeberangkan net antara dua tim yang saling berlawanan yang berahkir dengan perolehan angka atau pindah bola.

Viera (2004, p.121) menyatakan dalam bermain yang sesungguhnya dibutuhkan keterampilan dasar yang sistematis. Artinya, bermain bolavoli merupakan suatu urutan rangkaian permainan yang terdiri dari sebuah servis, yang kemudian dioperkan dengan menggunakan passing bawah atau passing atas ke arah pengumpan, kemudian mengumpankan kepada penyerang, memukul bola ke lapangan lawan, pada saat bersamaan di mana lawan juga mempersiapkan pertahanan dengan menggunakan blok, dan penerima di lapangan belakang, rangkaian ini terjadi secara terus-menerus selama pertandingan. Dari pendapat di atas dapat disimpulkan bahwa permainan bolavoli adalah permainan yang aktivitasnya berusaha saling menjatuhkan bola ke lantai lawan dengan cepat dengan tujuan memaksa regu lawan untuk tidak mampu mengembalikan bola sehingga tercetak skor/point.

Dalam rangka pengumpulan buktibukti tentang pencapian hasil belajar siswa penjasorkes pada permainan bolavoli di SMA melibatkan kegiatan pengukuran pada unjuk kerja siswa bermain bolavoli. Permainan bolavoli berorientasi pada kinerja yang melibatkan keterampilan gerak (skill movemet) (Bonnie, 2006, p.2). Penilaian otentik diakui sebagai cara lain untuk menilai belajar siswa dan meningkatkan pengajaran pendidikan jasmani (Hensley, 1997, pp.1924). Penilaian otentik digambarkan oleh Veal (2002, p.93) adalah adanya hubungan antara tugas-tugas instruksional sehari-hari dan penilaian.

Menurut Wiggins (1993, p.205) tugas pertama guru harus memutuskan apa yang penting bagi siswa untuk tahu. Ketika guru telah mendefinisikan apa yang siswa harus ketahui dan lakukan, barulah guru kemudian dapat merancang sebuah penilaian otentik tidak hanya untuk mencocokkan tujuan program sesuai dengan kurikulum, tetapi juga untuk mencocokkan instruksi tugas guru.

Penilaian otentik bercirikan sebagai penilaian berbasis kinerja, artinya siswa mengambil bentuk tugas. Hasil dari tugas berupa pekerjaan siswa yang disebut sebagai produk, dan mencetak rubrik atau panduan yang dikembangkan dan dirancang untuk sesuai dengan isi tugas dan digunakan untuk menilai produk siswa. Terdapat dua komponen penting dalam asesmen otentik, yaitu tugas kinerja (performance task) dan rubrik performansi (performance rubrics). 
Task merupakan tugas-tugas yang akan dilakukan untuk membuat asesmen kinerja, sedangkan rubrik terdiri dari daftar kriteria yang diwujudkan dengan dimensi-dimensi kerja, aspek proses atau konsep-konsep yang akan dinilai dan gradasi mutu mulai dari tingkat yang paling sempurna sampai dengan tingkat yang buruk (Zainul, 2005, p.13). Dalam pengukuran unjuk kerja diperlukan adanya reliabilitas, Johnson (2009, p.22) menyatakan "by reliability, we mean the consistency of examinees score across such factors as occasions, task, and raters. in others words, reliability addresses whether an examinees score would be the same if she were to take the exam on a different occasion, complete different tasks, or be scored by different raters".

Dalam penilaian otentik digunakan metode reliabilitas antar-rater, mengharuskan penilai melakukan pengamatan untuk menilai atau mengukur beberapa aspek perilaku siswa dalam tugas. Untuk mencapai tingkat keandalan antar-rater yang tinggi perlu dirancang dan diterapkan rubrik.

Pengembangan rubrik sangat diperlukan dalam penilaian kinerja, yang digunakan sebagai dasar pengukuran. Rubrik adalah pedoman dari produk suatu penilaian. Rubrik atau kriteria merupakan panduan untuk memberi skor yang jelas dan disepakati oleh guru dan siswa (Zainul, 2005, p.9). Panduan ini menjelaskan kepada guru dan siswa tentang standar yang ada dalam unjuk kerja (Winter, 1996, p.47).

Lund (2002, p.43) menyatakan bahwa "rubric indicate the criteria a person scoring performance-based assessment should use when doing evaluations". Lebih lanjut kriteria untuk penilaian unjuk kerja sering disebut scoring criteria, scoring guidelines, rubrics, and scoring rubric tetapi memiliki makna yang sama (Lund, 2002, p.44). Desain rubrik penilaian membutuhkan spesifikasi dari kriteria untuk menilai kualitas kinerja dan pilihan prosedur penilaian (Brenan, 2006, p.394). Kriteria dalam rubrik menggambarkan elemen-elemen penting dari unjuk kerja dan menjadi sumber kriteria yang akan dinilai.

Kriteria yang jelas merupakan esensi dalam penilaian unjuk kerja sehingga siswa dapat dinilai secara konsisten (Arter, 1996, p.vi). Kriteria rubrik yang digunakan guru adalah product criteria (Guskey 1996b, p.4). Kriteria produk adalah mengenai hasil apa dari siswa.

Dalam pendidikan jasmani kriteria produk sering disebut unjuk kerja siswa yang dicontohkan dalam produk kinerja siswa dalam bermain permainan olahraga (play to game) (Lund, 2002, p.45). Penilaian unjuk kerja mata pelajaran penjasorkes di SMA menerapkan penilaian unjuk kerja, di mana siswa diminta untuk melaksanakan tugas bermain bolavoli.

Penilaian unjuk kerja melibatkan dua macam relevansi, yaitu sesuai dengan kompetensi dan bermakna dalam kehidupan nyata, artinya sebuah kriteria atau indikator penilaian capaian hasil belajar harus cocok dengan kompetensi yang dibelajarkan dan sekaligus bermakna atau relevan dengan kehidupan nyata. Terkait dengan hal tersebut, pada penelitian dideskripsikan: (1) bentuk instrumen asesmen hasil belajar siswa penjasorkes pada permainan bolavoli yang tepat di sekolah menengah atas; (2) validitas instrumen asesmen hasil belajar siswa; (3) reliabilitas instrumen asesmen hasil belajar siswa penjasorkes pada permainan bolavoli di sekolah menengah atas yang dikembangkan; (4) prosedur penerapan asesmen hasil belajar siswa penjasorkes pada permainan bolavoli di sekolah menengah atas yang dikembangkan; (5) profil hasil belajar siswa penjasorkes pada permainan bolavoli di sekolah menengah atas berdasarkan asesmen yang dikembangkan.

\section{Metode Penelitian}

Jenis Penelitian

Penelitian ini menggunakan pendekatan penelitian pengembangan (Research and Development), karena sesuai dengan tujuan yang hendak dicapai, yaitu pengembangan asesmen hasil belajar siswa penjasorkes khususnya pada permainan bolavoli. Wujudnya berupa instrumen asesmen yang diharapkan dapat digunakan guru penjasorkes untuk memotret hasil belajar siswa pada materi 
permainan bolavoli di sekolah menengah atas.

Model penelitian pengembangan yang dipilih adalah model penelitian dan pengembangan yang dikembangkan oleh Borg and Gall (1983, p.772). Dasar peneliti menggunakan model penelitian pengembangan karena rangkaian langkah-langkah penelitian dan pengembangan dilakukan secara siklis, dan pada setiap langkah yang dilakukan selalu mengacu pada hasil langkah sebelumnya hingga pada akhirnya diperoleh suatu produk pendidikan baru.

Adapun langkah-langkah metode R \& D Borg \& Gall (1983, p.775) adalah; research and information collecting, planning, develop preliminary form of product, preliminary field testing, main product revision, main field testing, operational product revision, operational field testing, final product revision, dissemination and implementation.

Berdasarkan sepuluh langkah penelitian dan pengembangan yang dikembangkan Borg \& Gall tersebut, dalam penelitian ini pada proses pelaksanaannya melakukan adaptasi yang mengacu pada model pendekatan tersebut. Adapun adaptasi penelitian pengembangan ini secara garis besar terdiri dari empat tahap kegiatan pokok, yakni: (1) studi pendahuluan; (2) pengembangan produk; (3) uji coba dan revisi produk; dan (4) diseminasi produk hasil pengembangan.

\section{Waktu dan Tempat Penelitian}

Uji coba instrumen penilaian dilaksanakan pada bulan Januari 2013 kepada para siswa Sekolah Laboratorium Olahraga (SELABORA) FIK UNY yang melibatkan tiga puluh satu orang, meliputi subjek uji coba keseluruhan berjumlah dua puluh empat orang terdiri dari dua belas orang siswa putera dan dua belas orang siswa puteri yang berasal dari SMA Negeri di DIY, tiga orang guru sebagai rater, dua orang sebagai wasit, dan dua orang sebagai pengambil gambar video.

\section{Subjek Penelitian}

Sumber informasi dalam penelitian ini adalah semua siswa yang menempuh mata pelajaran penjasorkes pada Sekolah Menengah Atas di DIY. Populasi siswa SMA yang mengikuti mata pelajaran penjasorkes di DIY tersebar di empat kabupaten dan satu kotamadya, yaitu Kab. Sleman, Kab. Bantul, Kab.Kulon Progo, Kab. Gunung Kidul dan kota Yogyakarta. Peneliti mengambil kelas XI dari SMA negeri bukan dari SMA swasta, karena SMA Negeri dapat dijadikan tolak ukur dalam proses pembelajaran penjasorkes.

Sampel sumber informasi dalam penelitian ini terdiri atas dua elemen yaitu: (1) siswa kelas XI; dan (2) penilai atau rater dalam bidang permainan bolavoli yaitu dari guru bidang studi penjasorkes. Penentuan sampel dalam penelitian ini diambil secara purposive sampling dengan kriteria; (1) sekolah SMA Negeri yang menyelenggarakan kelas khusus yaitu kelas olahraga, (2) sekolah SMA Negeri yang minimal sudah merintis kelas olahraga. Sehingga diperoleh sampel siswa dari Kab.Sleman diambil dari SMAN 1 Seyegan, Kab.Kulon Progo diambil SMAN 2 Wates, Kab.Bantul diambil dari SMAN I Sewon, Kab.Gunung Kidul diambil SMAN 1 Tanjung Sari, dan Kota Madya Yogyakarta diambil SMAN 1 Yogyakarta. Jumlah siswa yang dijadikan sampel dari empat kabupaten, dan satu kota madya adalah 120 siswa yang terdiri 60 siswa putera dan 60 siswa puteri.

Instrumen dan Teknik Pengumpul Data

Asesmen hasil belajar siswa penjasorkes pada permainan bolavoli dilakukan dengan instrumen pengamatan (observasi) pada unjuk kerja siswa. Teknik pengumpulan data asesmen hasil belajar siswa penjasorkes pada permainan bolavoli di SMA menggunakan tugas unjuk kerja siswa bermain bolavoli 6 lawan 6 dibatasi tiga putaran posisi server pertama yang diamati menggunakan pedoman observasi dilengkapi dengan lembar rubrik.

Pedoman pengamatan dalam asesmen hasil belajar siswa penjasorkes pada permainan bolavoli dipergunakan untuk mengamati dan menilai setiap siswa peserta tes unjuk kerja dengan menggunakan rubrik 
berbentuk skala penilaian (rating scale) beserta bobot penilaiannya. Penyusunan konstruk instrumen pengamatan dalam bentuk skala penilaian berdasarkan materi yang mencerminkan keterampilan yang akan diukur. Selanjutnya, ditentukan skala penilaian untuk setiap materi. Dalam penelitian ini digunakan empat skala penilaian, yaitu satu sampai empat $(1-4)$. Skala tersebut dibagi menjadi dua bagian, yaitu kompeten dan tidak kompeten.

Penetapan standar kompetensi pada asesmen hasil belajar siswa penjasorkes pada permainan bolavoli berupa unjuk kerja siswa bermain bolavoli 6 lawan 6 mencakup kemampuan dalam persiapan saat akan memainkan bola, proses teknik memainkan bola, hasil penempatan bola dan sikap siswa dalam bermain. Apabila siswa memperoleh nilai $\geq 70 \mathrm{KKM}$ maka dikategorikan kompeten. Apabila siswa memperoleh nilai $<70$ KKM maka dikategorikan tidak kompeten dan harus menempuh remidi pada bagian yang tidak kompeten.

Penetapan standar kompetensi mengacu pada dua pendekatan metode Bookmark dan kriteria ketuntasan minimal (KKM). Metode Bookmark berkenaan dengan penetapan tingkat kesulitan (Hambleton \& Pitoniak, dalam Brenan, 2006, pp.442-444). Dalam teori respon butir, model logistik satu parameter adalah salah satu model item respons test (IRT) yang mengandung satu karakteristik item, yaitu tingkat kesulitan. Dalam metode Bookmark digunakan sebuah respon probabilitas 0,67 , yang menunjukkan titik skor yang ditetapkan panelis sebagai probabilitas respon.

Berdasarkan kedua sumber tersebut di atas dan kesepakatan antara guru penjasorkes, peneliti menetapkan KKM sebesar 70 sebagai pedoman penetapan standar kompeten pada asesmen hasil belajar siswa penjasorkes pada permainan bolavoli. Nilai KKM sebesar 70 yang dicapai siswa penjasorkes pada permainan bolavoli menunjukkan bahwa siswa mampu bermain bolavoli (mulai dari menyiapkan sikap awal tubuh yang sesuai dengan jenis teknik atau cara memainkan bola yang dipilih sampai hasil penempatan bola ke lapangan lawan beserta kemampuan kerjasama dan sportivitas).

\section{Teknik dan Analisis Data}

Dalam rangka untuk mengetahui apakah instrumen penelitian ini sudah memenuhi kriteria sebagai instrumen yang baik, diperlukan analisis. Sejauhmana instrumen pengamatan dapat mengukur hasil belajar siswa penjasorkes pada permainan bolavoli, untuk itu diperlukan adanya validasi. Konstruk instrumen pengamatan yang digunakan dalam asesmen hasil belajar siswa penjasorkes pada permainan bolavoli ini disesuaikan dengan aspek-aspek yang diperlukan dalam unjuk kerja nyata siswa bermain bolavoli 6 lawan 6 namun sebelum instrumen ini digunakan harus diuji validitas.

Penelitian ini berorentasi pada pencapaian hasil belajar sehingga penekannya lebih kepada validitas isi, karena berhubungan dengan kemampuan instrumen untuk menggambarkan secara tepat domain perilaku yang dinilai. Langkah validitas isi dijabarkan ke dalam aspek yang terinci dan dideskripsikan indikatornya.

Proses validasi instrumen pengamatan unjuk kerja siswa bermain bolavoli 6 lawan 6 berdasarkan exspert judgment melalui Focus Group Discussion (FGD). Forum ini melibatkan pendapat para pakar, yaitu: guru bidang penjasorkes SMA, dosen mata kuliah permainan bolavoli jurusan POR FIK UNY, praktisi dalam bidang penjasorkes, dan pakar pengukuran.

Penentuan koefisien reliabilitas instrumen asesmen hasil belajar siswa penjasorkes pada permainan bolavoli dilakukan dengan menggunakan koefisien Genova (Generalizability of varians). Program Genova mengacu pada teori Generalizability yang dikembangkan oleh Crick dan Brennan pada tahun 1983, yang terdiri dari Generalizability Study (G study) dan Decision Study (D study) dengan komponen variansinya adalah person, rater, dan item. G study digunakan untuk mengestimasi komponen variansi kesalahan yang diakibatkan oleh berbagai sumber variansi. $D$ study digunakan untuk menge- 
tahui koefisien reliabilitas (Retnowati, 2009, p.184).

Besarnya koefisien keandalan merupakan rasio antara varians sistematik atau varians sebenarnya dan varians total. Penelitian ini menggunakan GENOVA yang komponen variansnya adalah person $(\mathrm{P}), \operatorname{rater}(\mathrm{T})$, item (I), interaksi person dan rater, dan kesalahan. $G$ studynya menggunakan rancangan bersarang (nested design) dan D-study-nya juga menggunakan rancangan bersarang (nested design).

Penelitian ini menggunakan satu facet P x (I:T) G-study yang bersarang untuk mengestimasi varians komponen, varians kesalahan, generalizeability dan koefiesien phi untuk one-facet, nested, I:T D-study. Varians komponen yang berbaur pada rancangan bersarang (P,T:I,E) adalah jumlah varians komponen dalam $G$ study bersarang yang dapat ditulis sebagai berikut.

$$
\sigma^{2} p, r: i, e=\sigma^{2} p+\sigma^{2} r i e
$$

Keterangan:

$\mathrm{p}=$ person

$\mathrm{r}=$ guru $/$ rater

$\mathrm{i}=$ item

$\mathrm{r}: \mathrm{i}=$ rater bersarang pada item

e = kesalahan

Setelah varians komponen diperoleh, termasuk varians kesalahan, maka dapat diestimasi varians sebenarnya (true variance). Selanjutnya, dapat diestimasi besarnya indek keandalan hasil pengukuran, yaitu rasio varians sebenarnya terhadap varians keseluruhan komponen. Estimasi varians setiap komponen dan besarnya indeks keandalan hasil pengukuran dengan instrumen yang dikembangkan peneliti menggunakan paket program GENOVA.

Rancangan yang digunakan untuk Gstudy adalah P X (I:T), yaitu item bersarang pada rater, penilai dalam menilai anak bermain permainan bolavoli berinteraksi dengan anak yang bersarang pada item. Cara penilai atau rater $(\mathrm{T})$ dalam menilai siswa bermain permainan bolavoli 6 lawan $6(\mathrm{P})$ tergantung pada pendapat penilai terhadap item yang dinilai, sehingga dikatakan rater bersarang pada item.
Rancangan P X (I:T) ini berdasarkan analisis varians efek random memiliki efek utama: P, T, I:T dan efek interaksinya adalah PI, PT bersarang pada I. Jadi, ada varians person, varians rater, dan varians penilai bersarang pada I untuk efek utama, sedang untuk efek interaksinya adalah varians person item, varians rater yang bersarang pada item.

Besarnya varians $\mathrm{R}$ bersarang pada I dapat ditulis sebagai berikut:

$$
\boldsymbol{\sigma}^{2}(\mathbf{T}: \mathbf{I})=\boldsymbol{\sigma}^{2}(\mathbf{T}, \mathbf{T I})=\boldsymbol{\sigma}^{2}(\mathbf{T})+\boldsymbol{\sigma}^{2}(\mathbf{T I})
$$

Besarnya koefisien keandalan instrumen penilaian adalah:

$$
\mathbf{E} \boldsymbol{\rho}^{2}=\frac{\boldsymbol{\sigma}^{2}(\mathbf{P})}{\boldsymbol{\sigma}^{2}(\mathbf{P})+\boldsymbol{\sigma}^{2}(\boldsymbol{\delta})}
$$

$\mathrm{EP}^{2}$ adalah nilai harapan koefisien keandalan instrumen, $\sigma^{2}(\mathrm{P})$ adalah varians person (siswa) $\sigma^{2}(\delta)$ adalah varians kesalahan. Varians kesalahan terdiri atas varians rater, varians item, dan variansinteraksi rater item. Besarnya varians ini diestimasi dengan menggunakan teknikanalisis varians rancangan efek random. Untuk melihat reliabilitas dari kriteria instrumen penilaian permainan bolavoli hasil uji coba, digunakan analisis koefisien interrater.

Koefisien interrater adalah salah satu sarana untuk melihat tingkat konsistensi atau keajegan antar-rater dalam memberikan rating terhadap unjuk kerja siswa dalam bermain bolavoli. Untuk keperluan ini, digunakan koefisien Cohen's Kappa. Ada 3 (tiga) orang rater yang memberikan rating pada penilaian unjuk kerja bermain bolavoli 6 lawan 6 pada siswa putera dan puteri.

Pada penilaian persiapan saat akan memainkan bola, ada 5 (lima) item yang menjadi objek penilaian, pada penilaian proses teknik memainkan bola ada 15 (lima belas) item, penilaian hasil penempatan bola ada 7 (tujuh) item dan penilaian kemampuan menampilkan sikap saat bermain siswa ada 2 (dua) item. Selanjutnya nilai koefisien $x$ yang dihasilkan dibandingkan dengan kriteria minimal yang diperkenankan, yaitu 0,70 (Linn, 1990, p.143). Selanjutnya, asesmen hasil belajar siswa penjasorkes pada permainan bolavoli dianalisis dengan menggunakan teknik analisis deskriptif, yaitu 
mendeskripsikan penilaian yang dilakukan selama siswa melalukan tes unjuk kerja bermain bolavoli 6 lawan 6 .

\section{Hasil dan Pembahasan Penelitian}

Data Pendahuluan

\section{Hasil Analisis Kebutuban}

Dalam analisis kebutuhan lapangan peneliti mewancarai 22 orang guru mata pelajaran penjasorkes SMA yang berada di 5 wilayah kabupaten DIY. Ada 5 item yang diidentifikasi dalam studi awal ini, yaitu kurikulum, tujuan hasil belajar penjasorkes pada permainan, penggunaan perangkat penilaian, metodepenilaian, penggunaan instrumen.

Hasil wawancara yang dilakukan oleh peneliti berkaitan dengan masing-masing item tersebut dideskripsikan sebagai berikut.

Pengalaman guru penjasorkes dalam menentukan tujuan pembelajaran penjasorkes adalah berdasarkan kurikulum tingkat satuan pendidikan (KTSP) dan menggunakan gabungan KTSP dengan kurikulum sebelumnya. KTSP yang dikembangkan berdasarkan Standar Kompetensi dan Kompetensi Dasar Permen No 2 Tahun 2006 tentang standar isi pendidikan merupakan kurikulum terbaru yang digunakan pada jenjang sekolah dasar sampai sekolah menengah.

Tabel 1. Penggunaan Kurikulum

\begin{tabular}{clcc}
\hline $\begin{array}{c}\text { Urut- } \\
\text { an }\end{array}$ & Tanggapan & $\begin{array}{c}\text { Jumlah } \\
\text { Respon }\end{array}$ & \\
\hline 1 & Pengalaman guru dalam & 17 & 77,28 \\
& menentukan tujuan & & \\
& pembelajaran siswa berdasarkan & & \\
& kurikulum yang berlaku yaitu & & \\
& KTSP & & \\
\hline 2 & Pengalaman guru dalam & 5 & 22,72 \\
& menentukan tujuan & & \\
& pembelajaran siswa berdasarkan \\
& KTSP dan menggunakan & & \\
& gabungan dengan kurikulum & & \\
& sebelumnya & & \\
\hline $\mathrm{N}=22$ & &
\end{tabular}

Kurikulum yang digunakan sebelumnya adalah Kurikulum 2004, yaitu kurikulum berbasis kompetensi (KBK). Namun, dapat disimpulkan KTSP pada dasarnya sama dengan kurikulum 2004, perbedaannya hanya pada standar kompetensi yang ingin dicapai dan cakupannya.

Terkait dengan tujuan dan hasil belajar, pada kenyataannya prioritas hasil belajar pada penjasorkes pada permainan bolavoli di kalangan para guru sangat beragam. Keberagaman tersebut secara rinci dapat dilihat melalui jumlah respon, persentase, dan prioritas pilihan sebagaimana terangkum dalam Tabel 2.

Tabel 2. Tujuan dan Hasil Belajar Permainan Bolavoli pada Penjasorkes

\begin{tabular}{|c|c|c|c|}
\hline $\begin{array}{l}\text { Urut- } \\
\text { an }\end{array}$ & Aspek & $\begin{array}{l}\text { Jumlah } \\
\text { Respon }\end{array}$ & $\%$ \\
\hline 1 & $\begin{array}{l}\text { Penguasaan siswa pada aspek } \\
\text { proses teknik atau cara } \\
\text { memainkan bola yang diperoleh } \\
\text { melalui berbagai pengalaman } \\
\text { dalam bermain bolavoli } \\
\text { (menerima bola, mengumpan, } \\
\text { memukul, membendung, dan } \\
\text { lain-lain) membuat senang siswa. }\end{array}$ & 9 & 40,90 \\
\hline 2 & $\begin{array}{l}\text { Bermain bolavoli dan } \\
\text { keterkaitanya dengan aspek } \\
\text { kerjasama, sportivitas, menaati } \\
\text { aturan main, saling menghormati. }\end{array}$ & 5 & 22,72 \\
\hline 3 & $\begin{array}{l}\text { Aspek keterampilan siswa pada } \\
\text { hasil penempatan bola. }\end{array}$ & 8 & 36,36 \\
\hline
\end{tabular}

Dari data yang diperoleh menunjukkan bahwa sebagian guru masih berpendapat bahwa keterampilan siswa dalam memainkan bola atau penguasaan konsep dalam keterampilan bermain menjadi prioritas pertama yang akan dicapai dalam pembelajaran penjasorkes materi permainan bolavoli. Bahkan, di antaranya masih berpendapat pula bahwa bermain bolavoli dan keterkaitannya dengan berbagai aspek nilai-nilai yang terkandung namun tampak seperti kerja sama, sportivitas sebagai prioritas utama.

Meskipun demikian, berdasarkan tanggapan para guru dapat disimpulkan bahwa penguasaan konsep gerak siswa meliputi menerima bola, mengumpan, memukul bola dan membendung bola yang dilakukan melalui berbagai pengalaman teknik atau cara memainkan bola saat bermain ternyata tetap menjadi prioritas yang paling banyak dipilih

Pengembangan Asesmen Hasil Belajar PENJASORKES - 23 Guntur, Sukadiyanto, Djemari Mardapi 
oleh para guru. Selanjutnya, hal itu diikuti oleh prioritas guru dalam mencapai hasil belajar yang berupa unsur kerja sama siswa, sportivitas siswa dalam bermain bolavoli.

Keberhasilan pencapaian kompetensi siswa akan sangat ditentukan oleh pengalaman dan pengetahuan guru dalam mengembangkan, dan menggunakan alat ukur yang telah dikonstruksi itu dengan cara yang benar, serta kemampuan menganalisis informasi yang dihasilkan oleh alat ukur itu. Berkaitan dengan pengalaman guru dalam pengembangan perangkat instrumen yang digunakan dalam melakukan penilaian praktik bolavoli selama ini dapat dilihat melalui jumlah respon, persentase, dan prioritas pilihan sebagaimana terangkum dalam Tabel 3.

Tabel 3. Penggunaan Perangkat Penilaian

\begin{tabular}{clcc}
\hline Urutan & Perangkat Penilaian & $\begin{array}{c}\text { Jumlah } \\
\text { Respon }\end{array}$ & \\
\hline 1 & Kisi dan tugas praktik & 18 & 81,81 \\
2 & Lembar pengamatan & 4 & 18,18 \\
3 & Rubrik penilaian & 0 & 0 \\
4 & Prosedur Penilaian & 0 & 0 \\
\hline $\mathrm{N}=22$ & & &
\end{tabular}

Dari data yang diperoleh menunjukkan bahwa sebagian besar guru menyusun kisi dan suatu tes praktik sebelum dilakukan penilaian. Lembar pengamatan, rubrik penilaian dan prosedur penilaian tidak dibuat karena tes praktik yang digunakan oleh guru diadopsi dari tes-tes simulasi yang sudah memiliki perangkat penilaian berupa prosedur penilaian.

Meskipun demikian, berdasarkan tanggapan para guru dapat disimpulkan bahwa selama ini penguasaan guru paling utama hanya menyusun kisi dan tes praktik. Hal ini disebabkan karena pemahaman tentang pengembangan rubrik penilaian dan prosedur penilaian belum banyak dimengerti.

Hasil wawancara pada guru terkait dengan metode penilaian untuk mengukur kompetensi siswa pada materi permainan bolavoli yang digunakan oleh guru antara lain: tes praktik, pengamatan, tes tertulis, portofolio, penugasaan individu atau kelompok, tes lisan, dan jurnal. Berdasarkan pengalamannya, pada kenyataannya setiap guru memiliki prioritas yang berbeda terhadap ketujuh metode penilaian tersebut. Tanggapan para guru terhadap metode penilaian terangkum dalam Tabel 4.

Tabel 4. Metode Penilaian

\begin{tabular}{|c|c|c|c|}
\hline Urutan & Metode & $\begin{array}{l}\text { Jumlah } \\
\text { Respon }\end{array}$ & $\%$ \\
\hline 1 & Tes praktik (tes kinerja) & 15 & 68,18 \\
\hline 2 & Pengamatan (observasi) & - & - \\
\hline 3 & Tes tertulis & 7 & 31,82 \\
\hline 4 & Portofolio & - & 0 \\
\hline 5 & $\begin{array}{l}\text { Penugasaan individu atau } \\
\text { kelompok }\end{array}$ & - & 0 \\
\hline 6 & Tes lisan & - & 0 \\
\hline 7 & Jurnal & - & 0 \\
\hline
\end{tabular}

Berdasarkan data hasil wawancara dengan guru dapat disimpulkan bahwa, pada umumnya para guru menempatkan metode penilaian permainan bolavoli yang mencakup metode; tes praktik, dan tes tertulis sebagai prioritas pertama yang perlu diperhatikan. Metode pengamatan, tes portofolio, penugasan individu, tes lisan dan jurnal tidak sama sekali digunakan oleh guru.

Berdasarkan karakteristik yang dinilai dan instrumen yang digunakan guru dalam melakukan penilaian praktik bolavoli guru menggunakan mengadopsi tes keterampilan bolavoli dari berbagai macam tes. Informasi tersebut dapat disajikan pada Tabel 5 .

Tabel 5. Penggunaan Instrumen

\begin{tabular}{|c|c|c|c|}
\hline $\begin{array}{l}\text { Urut- } \\
\text { an }\end{array}$ & Instrumen & $\begin{array}{l}\text { Jumlah } \\
\text { Respon }\end{array}$ & $\%$ \\
\hline 1 & $\begin{array}{l}\text { Kemampuan siswa melakukan } \\
\text { teknik servis menggunakan } \\
\text { serving accuracy test dari } \\
\text { AHPPER }\end{array}$ & 5 & 22,72 \\
\hline 2 & $\begin{array}{l}\text { Kemampuan siswa melakukan } \\
\text { passing digunakan Brumbach } \\
\text { forearm pass wall-volley test dan } \\
\text { Kautz volleyball passing test }\end{array}$ & 5 & 22,72 \\
\hline 3 & $\begin{array}{l}\text { Kemampuan siswa melakukan } \\
\text { spike menggunakan Stanley } \\
\text { spike test }\end{array}$ & 5 & 22,72 \\
\hline 4 & $\begin{array}{l}\text { Kemampuan siswa bermain } \\
\text { bolavoli dengan menggunakan } \\
\text { brady volley test }\end{array}$ & 7 & 31,81 \\
\hline
\end{tabular}


Dari data yang diperoleh menunjukkan bahwa sebagian besar guru menggunakan tes keterampilan tersebut untuk menilai keterampilan siswa pada masing-masing teknik atau cara memainkan bola dalam bolavoli. Pelaksanaanya berupa simulasi secara terpisah pisah antar-item butir sehingga dalam melakukan penilaian, guru belum menggunakan perangkat penilaian sebagai satu sistem penilaian yang menyatu.

\section{Data Pengembangan Produk}

Pengembangan ini bertujuan sebagai tindak lanjut dari hasil analisis kebutuhan guru penjasorkes yang membutuhkan instrumen yang bisa mengakses hasil belajar penjasorkes pada permainan bolavoli di SMA. Langkah yang ditempuh peneliti dalam tahap pengembangan ini antara lain mencakup kegiatan perencanan dan perancangan produk, dan kegiatan focus group disccuson (FGD) sehingga pada akhir kegiatan ini dihasilkan produk berupa instrumen sistem asesmen hasil belajar materi permainan bolavoli pada mata pelajaran penjasorkes di SMA.

\section{Data Uji Coba Produk}

Dalam tahap ini dilakukan uji coba lapangan dan sekaligus revisi produk produk instrumen asesmen hasil belajar siswa penjasorkes pada permainan bolavoli di SMA. Secara berturut-turut dilakukan dua kegiatan pokok yaitu pra-ujicoba dan uji coba instrumen yang dikembangkan.

\section{Data Validitas Instrumen}

Validitas adalah suatu ukuran untuk menunjukkan sejauhmana suatu alat pengukur itu dapat mengukur apa yang hendak diukur. Instrumen asesmen hasil belajar siswa penjasorkes pada permainan bolavoli ini menggunakan validitas isi.

Validitas isi dimaksudkan untuk mengukur sejauh mana butir-butir instrumen yang digunakan mencakup keseluruhan isi objek yang diukur. Validitas isi instrumen penelitian ini dilakukan dengan menggunakan analisis rasional yaitu apakah butir pada kisi-kisi instrumen menggambarkan indikator dari variabel yang diukur dari unjuk kerja dalam penelitian. Adapun langkah-langkah yang di- lakukan dalam validitas isi adalah melaksanakan FGD tahap II dengan para pakar ahli untuk memeriksa isi instrumen secara sistematis untuk mengevaluasi relevansi dengan variabel yang telah ditentukan.

Langkah ini telah dilakukan pada tahap validasi untuk mereview produk awal berupa perangkat instrumen. Berdasarkan hasil dari FGD tahap II menurut pendapat para ahli tentang kisi-kisi unjuk kerja siswa bermain bolavoli yang dikembangkan sudah mencerminkan materi yang terdapat dalam kurikulum KTSP SMA khususnya kelas XI/ 2 dan profil unjuk kerja siswa. Butir-butir keterampilan dan kemampuan yang disusun pada pedoman pengamatan sudah mencerminkan penguasaan kompetensi siswa sehingga validitas instrumen penilaian pengamatan unjuk kerja bermain bolavoli yang dikembangkan termasuk kategori baik.

\section{Data Reliabilitas Instrumen}

Bagian ini mendeskripsikan tentang hasil uji coba penggunaan perangkat instrumen penilaian yang diujicobakan kepada tiga orang guru sebagai penilai terhadap unjuk kerja siswa bermain permainan bolavoli. Indikator yang digunakan sebagai acuan untuk melakukan rating oleh para penilai telah diperoleh dari hasil pengembangan pada tahap sebelumnya.

Pedoman pengamatan tugas unjuk kerja siswa bermain bolavoli 6 lawan 6 ini terdiri atas empat indikator yakni: (1) penilaian keterampilan persiapan siswa saat akan memainkan bola; (2) penilaian keterampilan proses teknik memainkan bola; dan (3) penilaian keterampilan hasil penempatan bola; dan (4) penilaian kemampuan siswa menampilkan sikap dalam bermain. Hasil analisis $G$ study digunakan untuk mengetahui koefisien reliabilitas alat penilaian yang dikembangkan serta estimasi komponen variansi kesalahan yang diakibatkan oleh berbagai sumber variansi, dalam pengembangan ini yakni sumber variansi siswa $(\mathrm{P})$, penilai $(\mathrm{T})$ dan item $(\mathrm{I})$.

Setelah koefisien $G$ dapat diketahui, maka pada tahapan analisis lanjut (analisis D study) akan didapatkan informasi tentang keputusan seberapa jauh penggunaan instrumen yang telah diuji memiliki keberlakuan 
pada faset yang lebih luas terutama menyangkut kesamaan kondisi pengukuran, dan dapat diterimanya kondisi faset tersebut bagi penilai yang lain.

Hasil G study untuk mengetahui tingkat kebermaknaan penggunaan instrumen pengamatan pada unjuk kerja siswa bermain bolavoli dari uji coba di lapangan dapat dirangkum pada Tabel 6.

Tabel 6. Rangkuman Hasil Koefisien $G$ Study pada Unjuk Kerja Bermain Bolavoli

\begin{tabular}{|c|c|c|c|c|c|}
\hline $\mathrm{No}$ & Komponen & $\begin{array}{l}\text { Uji } \\
\text { Faset } \\
\text { siswa }\end{array}$ & $\begin{array}{l}\text { Jumlah } \\
\text { Item }\end{array}$ & $\begin{array}{c}\text { Koefisien } \\
\text { Genova }\end{array}$ & $\begin{array}{c}\text { Rerata } \\
\text { Koefisien } \\
\text { G }\end{array}$ \\
\hline \multirow[t]{2}{*}{1} & \multirow{2}{*}{$\begin{array}{l}\text { Persiapan saat } \\
\text { akan memainkan } \\
\text { Bola }\end{array}$} & $\mathrm{Pa}$ & 5 & $0,90^{*}$ & $0,90 *$ \\
\hline & & $\mathrm{Pi}$ & 5 & $0,91 *$ & \\
\hline \multirow[t]{2}{*}{2} & \multirow{2}{*}{$\begin{array}{l}\text { Proses teknik } \\
\text { memainkan bola }\end{array}$} & $\mathrm{Pa}$ & 15 & $0,86^{*}$ & $0,84^{*}$ \\
\hline & & Pi & 15 & $0,83^{*}$ & \\
\hline \multirow[t]{2}{*}{3} & \multirow{2}{*}{$\begin{array}{l}\text { Hasil penempatan } \\
\text { bola }\end{array}$} & $\mathrm{Pa}$ & 7 & $0,75^{*}$ & $0,73^{*}$ \\
\hline & & $\mathrm{Pi}$ & 7 & $0,71 *$ & \\
\hline \multirow[t]{2}{*}{4} & \multirow{2}{*}{$\begin{array}{l}\text { Sikap dalam } \\
\text { bermain }\end{array}$} & $\mathrm{Pa}$ & 2 & $0,79 *$ & $0,83^{*}$ \\
\hline & & $\mathrm{Pi}$ & 2 & $0,87^{*}$ & \\
\hline \multirow[t]{2}{*}{5} & \multirow{2}{*}{$\begin{array}{l}\text { Semua } \\
\text { komponen }\end{array}$} & $\mathrm{Pa}$ & 29 & $0,78^{*}$ & $0,82 *$ \\
\hline & & $\mathrm{Pi}$ & 29 & $0,83^{*}$ & \\
\hline
\end{tabular}

*) memenuhi syarat menurut kriteria standar minimal 0,70 (Linn,1995, p.106)

Koefisien $\mathrm{G}$ dari komponen-komponen unjuk kerja bermain bolavoli menunjukkan bahwa secara keseluruhan pengembangan instrumen asesmen hasil belajar siswa penjasorkes pada permainan bolavoli dapat diterima untuk digunakan melakukan penilaian pada faset yang lebih luas. Dengan kata lain telah memenuhi untuk kepentingan faset pengukuran yang berkaitan dengan objek pengukuran pada unjuk kerja siswa bermain bolavoli yakni ditunjukkan oleh indeks koefisien $G$ sebesar 0,82. Koefisien $G$ study yang diperoleh menunjukkan bahwa nilai koefisien $G$ Study lebih besar dari kriteria yang ditentukan, yaitu 70 .

Dengan demikian, bentuk instrumen pengamatan unjuk kerja siswa bermain bolavoli dapat digunakan sebagai acuan guru dalam melakukan penilaian pada faset yang lebih luas. Namun, jika dilihat dari varian kesalahan untuk masing-masing komponen penilaian pada analisis Genova untuk unjuk kerja siswa bermain bolavoli masih memerlukan penyempurnaan dalam hal administrasi penyelenggaraan yakni harus meningkatkan keterampilan dan pengalaman agar diperoleh hasil pengukuran yang konsisten.

Konfirmasi data hasil uji coba dari hasil Anava, berikut ini disajikan hasil analisis koefisien interrater. Koefisien interrater merupakan salah satu sarana untuk melihat tingkat konsistensi atau keajegan antar penilai dalam memberikan rating terhadap unjuk kerja siswa bermain bolavoli. Untuk keperluan ini, peneliti menggunakan koefisien Cohen's Kappa. Rangkuman koefisien dapat ditunjukkan pada Tabel 7.

Tabel 7. Rangkuman Hasil Koefisien $\boldsymbol{K}$

\begin{tabular}{|c|c|c|c|c|}
\hline \multicolumn{5}{|c|}{ (Kappa) } \\
\hline No & $\begin{array}{c}\text { Kompone Bermain } \\
\text { Bolavoli }\end{array}$ & $\begin{array}{c}\text { Sasaran } \\
\text { Uji }\end{array}$ & $\begin{array}{c}\text { Koefisien } \\
\text { Kappa }\end{array}$ & $\begin{array}{c}\text { Rerat } \\
\text { Koefisie } \\
\text { (Kappa) }\end{array}$ \\
\hline \multirow[t]{2}{*}{1.} & \multirow{2}{*}{$\begin{array}{l}\text { Keterampilan } \\
\text { Persiapan Saat akan } \\
\text { Memainkan Bola }\end{array}$} & $\mathrm{Pa}$ & 0,78 & \multirow[t]{2}{*}{0,79} \\
\hline & & $\mathrm{Pi}$ & 0,80 & \\
\hline \multirow[t]{2}{*}{2.} & \multirow{2}{*}{$\begin{array}{l}\text { Keterampilan } \\
\text { Proses Teknik } \\
\text { Memainkan Bola }\end{array}$} & $\mathrm{Pa}$ & 0,79 & \multirow[t]{2}{*}{0,78} \\
\hline & & Pi & 0,77 & \\
\hline \multirow[t]{2}{*}{3.} & \multirow{2}{*}{$\begin{array}{l}\text { Keterampilan Hasil } \\
\text { Penempatan Bola }\end{array}$} & $\mathrm{Pa}$ & 0,80 & \multirow[t]{2}{*}{0,80} \\
\hline & & Pi & 0,80 & \\
\hline \multirow[t]{2}{*}{4.} & \multirow{2}{*}{$\begin{array}{l}\text { Kemampuan } \\
\text { Menampilkan Sikap } \\
\text { Dalam Bermain } \\
\text { Siswa }\end{array}$} & $\mathrm{Pa}$ & 0,81 & \multirow[t]{2}{*}{0,79} \\
\hline & & Pi & 0,78 & \\
\hline \multirow[t]{2}{*}{5} & \multirow[t]{2}{*}{ Semua komponen } & $\mathrm{Pa}$ & 0,79 & \multirow[t]{2}{*}{0,79} \\
\hline & & Pi & 0,78 & \\
\hline
\end{tabular}

Tabel 7 dapat memberikan gambaran bahwa hasil analisis kesepakatan dan kesepahaman rater terhadap konstruk instrumen pada empat komponen penilaian siswa dalam bermain dengan teknik Kappa pada siswa putera diperoleh koefisien sebesar 0,79. Berdasarkan besarnya koefisien reliabilitas antar-rater yang diperoleh hasilnya memenuhi syarat reliabilitas.

\section{Data Penerapan Prosedur Asesmen}

Prosedur pelaksanaan asesmen hasil belajar siswa penjasorkes pada permainan bolavoli yaitu alur atau langkah-langkah yang dilakukan dalam melakukan penilaian mencakup (1) kriteria rater atau penilai; (2) in- 
strumen penilaian yang digunakan meliputi: (a) pedoman pengamatan mencakup indikator dan deskrepsi unjuk kerja; (b) tugas unjuk kerja bermain bolavoli 6 lawan 6 dibatasi tiga putaran server pertama; (c) rubrik adalah rubric sebagai suatu alat penskoran yang terdiri dari daftar seperangkat kriteria beserta bobot penilaiannya dan skala penskoran 1-4 yang digunakan untuk mengamati hasil unjuk kerja siswa pada pedoman pengamatan atau observasi; (3) interpretasi data hasil unjuk kerja siswa yaitu informasi yang menyatakan tentang penguasaan kompetensi. Hasil wawancara dan pendapat para guru penjasorkes berkaitan dengan penerapan penggunaan prosedur pelaksanaan asesmen hasil belajar siswa penjasorkes pada permainan bolavoli menyatakan dapat dengan mudah digunakan untuk mengukur kemampuan dan keterampilan siswa dalam permainan bolavoli.

\section{Data Profil Hasil Belajar Siswa Penjasorkes pada Permainan Bolavoli di SMA}

Profil hasil belajar siswa penjasorkes pada permainan bolavoli ini berdasarkan pada data hasil penilaian pengamatan pada tes unjuk kerja siswa bermain bolavoli 6 lawan 6 sehingga pada bagian ini akan dideskripsikan profil unjuk kerja siswa bermain pada empat aspek yaitu: 1) keterampilan persiapan saat akan memainkan bola; 2) keterampilan proses teknik memainkan bola; 3) keterampilan hasil penempatan bola; dan (4) kemampuan menampilkan sikap dalam bermain.

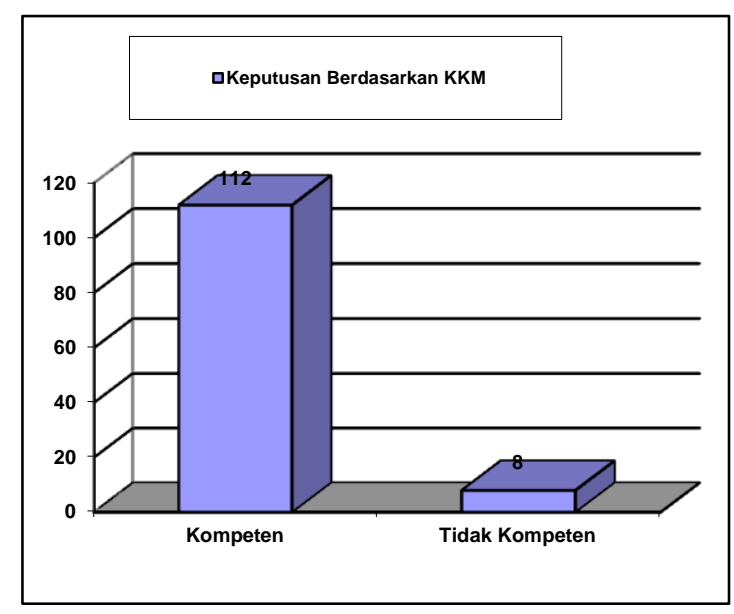

Gambar 1. Profil Hasil Belajar Siswa Penjasorkes Pada Permainan Bolavoli SMA
Gambar 1 menunjukkan bahwa prestasi yang dicapai dari 120 siswa dalam unjuk kerja bermain bolavoli pada mata pelajaran penjasorkes berdasarkan perolehan skor adalah 112 orang siswa memperoleh skor $\geq 70$ masuk dalam kategori kompeten dan 8 siswa memperoleh skor $<70$ masuk dalam kategori tidak kompeten.

Berdasarkan pada hasil analisis deskriptif dapat disimpulkan bahwa asesmen hasil belajar siswa penjasorkes pada permainan bolavoli di SMA DIY menunjukkan 120 orang siswa dinyatakan kompeten sebanyak 93,3\% atau sebanyak 112 orang siswa. Siswa yang dinyatakan tidak kompeten sebesar $6,7 \%$ atau sebanyak 8 orang siswa

\section{Simpulan}

Berdasarkan hasil analisis data dan pembahasan, maka dapat diajukan simpulan sebagai berikut: (1) bentuk instrumen asesmen hasil belajar siswa penjasorkes pada permainan bolavoli di SMA adalah pedoman pengamatan (observation) yang mencakup: (a) indikator; (b) deskripsi indikator; (c) rubrik dan; (d) prosedur asesmen; (2) validitas isi instrumen asesmen hasil belajar siswa penjasorkes pada permainan bolavoli berdasarkan expert judgement termasuk kategori baik; (3) reliabilitas instrumen asesmen hasil belajar siswa penjasorkes pada permainan bolavoli dianalisis dengan menggunakan paket program Genova menghasilkan koefisen interrater sebesar 0,82, dan Cohen's Kappa menghasilkan koefisien sebesar 0,79, keduanya memenuhi syarat reliabilitas; (4) prosedur pelaksanaan asesmen hasil belajar siswa penjasorkes pada permainan bolavoli berdasarkan pendapat para guru penjasorkes dapat digunakan; (5) profil hasil belajar siswa penjasorkes pada permainan bolavoli di Sekolah Menengah Atas menunjukkan bahwa 112 siswa (93\%) dinyatakan kompeten dan sebanyak 8 siswa $(6,7 \%)$ dinyatakan tidak kompeten.

Saran

Berdasarkan hasil penelitian ini disarankan sebagai berikut: (1) untuk mendapatkan informasi hasil belajar siswa penjasorkes pada permainan bolavoli yang otentik, 
instrumen asesmen hasil belajar ini dapat diterapkan oleh para guru dalam pembelajaran penjasorkes di SMA; (2) untuk mengembangkan instrumen asesmen pembelajaran penjaskesorkes lebih lanjut, pihak sekolah dan atau guru dapat mengembangkan instrumen asesmen yang lain berdasarkan kebutuhan dan kompetensi dasar yang ada; (3) penilai dalam melakukan asesmen pada mata pelajaran penjasorkes harus memiliki bukti inter-rater yang baik.

\section{Daftar Pustaka}

Asmawi, Moch. (2006). Dimensi pembelajaran keterampilan gerak dalam pendidikan jasmani. Jurnal Majalab Olabraga. Yogyakarta: Fakultas Ilmu Keolahragaan Universitas Negeri Yogyakarta. Edisi Agustus.

American Sport Education Program. (2007). Coaching youth volleyball. Human Kinetics: USA.

Arter, J. (1996). Performance criteria: the heart of the matter. Ed. R. E. Blum \& J. A. Arter. A handbook for student performance assessment. Alexandria, VA: Assosiation for Supervision and Curriculum Development.

BSNP. (2007). Panduan penilaian kelompok mata pelajaran jasmani olabraga dan kesehatan: Jakarta: Depdiknas

Borg \& Gall. (1983). Educational research: an introduction. New York: Longman.

Barbara L. Viera. (2004). Step to success: Bolavoli tingkeat pemula. Terjemahan oleh PT Raja Grafindo Persada. Jakarta.

Berk, R.A. (1986). Performance assessment. Baltimore: The John Hopkins University Press.

Bonnie Kenny \& Cindy Gregory. (2006) Volleyball step to success: Sportinstruction series. USA: Human Kinetics.

Brennan, R,L. (2006). Educational measurement. Westport: Praeger.

Crum, Bart. (2006). Substantial view of the body, Paper, In Service Training On
Didactic Of Sport Games. Seminar. Bandung: Universitas Pendidikan Indonesia.

Depdiknas. (2003). Pedoman khusus pengembangan silabus dan penilaian mata pelajaran pendidikan jasmani. Jakarta: Ditjendikdasmen.

Els van der Werf. (2006). An innovation perspective on internationalisation of higher education: The critical phase. Journal of Studies in International Education, 3(1), 3-14.

Grineski, S. (1989). Children, Games, and prosocial behavior: Insihts and connections. Journal of physical education, recreation and dance, 60 (8), 20-25.

Guskey, T. (1996b). Alternative ways to document and communicate student learning. Alexandria, VA: Association for supervision and curriculum development.

Hayton, G. \& Wagner, Z. (1998). Performance assessment in vocational education and training. Australian and New Zealand Journal of Vocational Education Research, vol 6, no. 1, pp.69-85.

Hensley, L.D. (1997). Authentic skill assesment in physical education. Journal of physical education, recreation and dance, vol 7 pp.19-24.

Hopper, T. (1998). Teaching games centred games using progressive principles of play. Canadian Association for Health, Physical Education, Recreationand Dance Journal, 64 (3), 4-7.

Jennifer Beasley. (2009). Assessing student learning: A common sense guide. Bolton, MA: Anker Publishing

Jewett, dan A. Nixon, J. (1995). An Introduction to physical education Philadelphia: Saunders College.

Joel, Dearing. (2003). Sport fundamentals series volley ball fundamentals a better way to learn the basic. USA: Human Kinetics.

Johnson, R.L., Penny, J.A., \& Gordon, B. (2009). Assessing performance: de-signing, 
scoring, and validating per-formance task. London: The Guilford Pres.

Kinda S. Lenberg. (2006). Volleyball skills \& drills. American volleyball Coaches Association. USA: Human Kinetics.

Keating, J. (2001). Sportsmanship as a moral category. Champaign: Iiiionis: Human Kinetics.

Linn, R. L., \& Gronlund, N. E. (1995). Measurement and assessment in teaching. Seventh Edition.Englewood Cliff: Merril, an imprint of Prentice Hall.

Lund, J.L \& Mary Fortman Kirk. (2002). Performance based assessment for middle and high school physical education.USA: Human Kinetics.

Lutan, R. (2001). Mengajar pendidikan jasmani pendekatan pendidikan gerakdi Sekolah Dasar: Jakarta: Direktorat Jendral Olahraga: Depdiknas.

Mardapi, Djemari. (2012). Pengukuran penilaian dan evaluasi pendidikan. Yogyakarta: Nuha Litera.

Metzler, M. W. (2005). Instructional Models for Physical Education (2 Arizona: Holcomb Hathaway Publishers.

Mitchell, S. A. (1999). Teaching games for understanding:Theory, research and practice. Champaign. IL: Human Kinetics

Nitko, J., Anton \& Brookhart, Susan. M. (2007). Educational assessment for students. New Jersy: Merill Prentice Hall.

Nurhasan. (2001). Tes dan pengukuran dalam pendidikan jasmani: prinsip-prinsip dan penerapannya: Ditjen Pendidikan dasar dan Menengah.

Retnowati, Trie Hartiti. (2009). Pengembangan instrument penilaian seni lukis anak di Sekolah Dasar. Disertasi. Tidak dipublikasikan Yogyakarta: Universitas Negeri Yogyakarta.
Stiggins, R. (1997). The design and development of performance assessments. Educational Measurement: Issues and Practice 2nded. Upper Saddle River, NJ: Prentice Hall.

Tomme, P. M \& Wendt, J. C. (2003). Affective: Psycho-social of physical education. Journal of Physical Education, Recreation \& Dance; Oct 2003;54, 8; Reaserch Libary pg.66.

Veal, M. (2002). The role of assessment in secondary physical education Apedagogical view. Journal of Physical Education, Recreation \& Dance, 63(7), 88-92.

Vicki Worrell. (2002). Assessing the cognitive and affective progress of children. Journal of Physical Education, Recreation \& Dance; Sep; 2002; 73, 7; Research Library pg.29.

Yudiana, Y. \& Subroto, T. (2010). Permainan bolavoli. Bandung: Fakultas Pendidikan Olahraga dan Kesehatan Universitas Pendidikan Indonesia.

Wiggins, G. (1991). Standards, not standardization Evoking quality student work. Journal of Physical Education, Recreation \& Dance; April 1991; 48(5) Research Libary pg.18-25.

Wiggins, G. (1991). Standards, not standardization Evoking quality student work. Journal of Physical Education, Recreation \& Dance; April 1991; 48(5) Reaserch Library pg.18-25.

Wiggins, G. (1993). Assessing student performance. San Francisco: Jossey Bass Publishers.

Wuest, D. \& Bucher, C. (2009). Foundations of physical education, Exercise science and sport (16 $6^{\text {th }}$.Ed.). New York: McGraw-Hill.

Zainul, Asmawi. (2005). Alternative Assessment. Jakarta: Dirjen Dikti. 